\title{
Isolation and identification of bovine tuberculosis in a Brazilian herd (São Paulo)
}

\author{
AFC Nassar ${ }^{+}$, S Miyashiro, CG Oliveira*, WA Pacheco, RA Ogata** \\ Instituto Biológico, Av. Conselheiro Rodrigues Alves 1252 04014-002 São Paulo, SP, Brasil *Coordenadoria de Assistência Técnica \\ Integral, São Paulo, SP, Brasil **Universidade de São Paulo, São Paulo, SP, Brasil
}

Mycobacterium was verified in animals from a Brazilian dairy herd, a total of 42 samples from 30 cows were submitted to culture and the isolated strains were analyzed by two polymerase chain reaction (PCR), the first specific for species belonging to the Mycobacterium complex (MTBC) and the other for differentiating $\mathrm{M}$. tuberculosis from M. bovis. Twenty seven samples (64.3\%) from 18 animals (60\%) were positive for mycobacteria by culture, including samples from 15 retrofaryngeal lymphnodes (55.5\%), 9 prescapular lymphnodes (33.3\%), 2 lungs (7.4\%), and 1 liver (3.7\%). All isolated colonies were confirmed by PCR to contain MTBC organisms, and were identified as M. bovis by the same methodology.

Key words: tuberculosis - bovine - Mycobacterium bovis - intradermal tuberculin test - isolation - polymerase chain reaction

Bovine tuberculosis (TB), caused mainly by $\mathrm{Myco-}$ bacterium bovis is a disease causing considerable economic losses related to affected herds (Abrahão 1999). While most cases of human tuberculosis are caused by M. tuberculosis, infections caused by $M$. bovis are being increasingly documented as being the cause of epidemic nosocomial bursts in Paris (Bouvet et al. 1993). From a clinical and epidemiological perspective, a rapid method to differentiate both species is important for timely diagnosis, effective treatment (due to the intrinsic resistance of $M$. bovis to pirazynamide) and epidemiology of TB (Shah et al. 2002).

The bovine population in Brazil consists of about 180 million animals, with prevalence of TB ranging between 0.9 and $2.9 \%$ depending on the region and kind of production (Kantor \& Ritacco 1994). Between 1989 and 1998, official notification data indicated a national prevalence of $1.3 \%$ of infected animals (Brasil 2005). Due to disgonic and very slow growth, the identification of $M$. bovis by conventional biochemical methods is cumbersome and timeconsuming. Polymerase chain reaction (PCR) is a sensitive and fast diagnostic tool that can be used to detect the agent in clinical samples in $48 \mathrm{~h}$, but the presence of inhibitors in samples can interfere with its performance (Haddad et al. 2004, Singh et al. 2004, Brasil 2005).

Among the several PCR systems developed for detection of species composing the $M$. tuberculosis complex (MTBC) (Wards et al. 1995, Brasil 2005), we focused on two. One was described by Niyaz Ahmed et al.

+Corresponding author: nassar@biologico.sp.gov.br Received 13 December 2006

Accepted 28 June 2007
(1999) and based on specific primers (NZ1 and NZ2) for the insertion sequence IS 1081, selectively present in organisms of the MTBC. A multiplex-PCR with primers JB and specific primers for the gene encoding for pyrazinimidase (pncA) was reported by Shah et al. (2002) to differentiate between $M$. bovis and M. tuberculosis on colonies in culture and this method could detect less than $20 \mathrm{pg}$ of DNA, and this last reaction was the second applied reaction in the present work for differentiation between M. bovis and M. tuberculosis.

We here present our work aiming at the detection of M. bovis mainly in retrofaryngeal lymphnode samples of bovines from a herd of Tatuí (São Paulo, Brazil) by microbiological culture, and MTBC and M. bovis specific PCR systems, and comparing the microbiological results with the positive or inconclusive results at single intradermal comparative tuberculin test (SICTT) presented by these animals.

Thirty bovines from a Tatuí herd in São Paulo, Southeast Brazil and with positive (>4 mm) or inconclusive (2 to $3.9 \mathrm{~mm}$ ) response to SICTT were taken to sanitary slaughter. We collected 42 samples composed of the retrofaryngeal lymphnodes independent of the presence or not of suggestive lesions for TB while this was perfomed for prescapular lylmphnodes, lung, and liver only when presenting characteristic lesions of TB (Table). Samples were maintained in sterile bags at $4^{\circ} \mathrm{C}$ for transport to the Laboratory of Tuberculosis of Instituto Biológico, São Paulo, Brazil until futher analysis.

For culturing, samples were decontaminated by means of the Petroff method (Kantor 1979) and each one was inoculated in two tubes with Stonebrink and Petragnani medium, incubated at $37^{\circ} \mathrm{C}$, and examined for presence of micobacteria growth weekly, during 90 days.

One or two colonies from each positive culture were suspended in $200 \mu \mathrm{l}$ sterile saline solution $(0.85 \% \mathrm{NaCl})$ and boiled for 5 min for DNA liberation as described by Bermer-Melchior and Drugeon (1999). Ten microliter of each of these were submitted to the PCR reactions for detection of species of the MTBC and for differentiation of M. tuberculosis and M. bovis. 
TABLE

Samples collected at slaughterhouse from Tatui, SP, Brazil - 2006

\begin{tabular}{|c|c|c|c|c|c|c|c|}
\hline \multirow[b]{2}{*}{$\begin{array}{l}\text { Animal } \\
\text { identification }\end{array}$} & \multirow[b]{2}{*}{ SICTT (mm) } & \multirow[b]{2}{*}{$\begin{array}{l}\text { Collected } \\
\text { samples }\end{array}$} & \multirow[b]{2}{*}{ Lesion } & \multirow[b]{2}{*}{$\begin{array}{l}\text { Microbiological } \\
\text { culture }\end{array}$} & \multicolumn{3}{|c|}{ PCR } \\
\hline & & & & & $\mathrm{NZ}$ & $\begin{array}{l}\text { pncA- } \\
\text { M. bovis }\end{array}$ & $\begin{array}{l}\text { pncA- } \\
\text { M. tuberculosis }\end{array}$ \\
\hline 1 & Inconclusive (2.7) & $\mathrm{A}$ & $\mathrm{AL}$ & Positive & Positive & Positive & Negative \\
\hline 2 & Positive (8.2) & $\mathrm{A}$ & PL & Negative & - & - & - \\
\hline 3 & Positive (8.4) & A & PL & Negative & - & - & - \\
\hline 4 & Positive (5.0) & $\mathrm{A}$ & PL & Positive & Positive & Positive & Negative \\
\hline \multirow[t]{4}{*}{5} & Positive (8.4) & A & PL & Positive & Positive & Positive & Negative \\
\hline & & $\mathrm{B}$ & PL & Positive & Positive & Positive & Negative \\
\hline & & $\mathrm{C}$ & PL & Positive & Positive & Positive & Negative \\
\hline & & $\mathrm{D}$ & PL & Positive & Positive & Positive & Negative \\
\hline 6 & Positive (12.8) & A & $\mathrm{AL}$ & Positive & Positive & Positive & Negative \\
\hline \multirow[t]{2}{*}{7} & Positive (8.3) & A & PL & Positive & Positive & Positive & Negative \\
\hline & & $\mathrm{B}$ & PL & Positive & Positive & Positive & Negative \\
\hline 8 & Positive (15.9) & A & PL & Negative & - & - & - \\
\hline 9 & Positive (5.4) & A & PL & Positive & Positive & Positive & Negative \\
\hline \multirow[t]{2}{*}{10} & Inconclusive (3.2) & A & $\mathrm{AL}$ & Positive & Positive & Positive & Negative \\
\hline & & $\mathrm{B}$ & PL & Positive & Positive & Positive & Negative \\
\hline \multirow[t]{2}{*}{11} & Positive (6.5) & A & AL & Negative & - & - & - \\
\hline & & $\mathrm{B}$ & PL & Positive & Positive & Positive & Negative \\
\hline \multirow[t]{2}{*}{12} & Positive (8.8) & $\mathrm{A}$ & $\mathrm{AL}$ & Negative & - & - & - \\
\hline & & $\mathrm{B}$ & PL & Positive & Positive & Positive & Negative \\
\hline \multirow[t]{2}{*}{13} & Positive (5.6) & A & $\mathrm{AL}$ & Positive & Positive & Positive & Negative \\
\hline & & $\mathrm{B}$ & PL & Positive & Positive & Positive & Negative \\
\hline 14 & Positive (5.1) & A & PL & Positive & Positive & Positive & Negative \\
\hline 15 & Positive (7.5) & A & PL & Positive & Positive & Positive & Negative \\
\hline 16 & Positive (5.1) & A & $\mathrm{AL}$ & Negative & - & - & - \\
\hline 17 & Positive (18.5) & A & PL & Negative & - & - & - \\
\hline 18 & Positive (5.6) & A & $\mathrm{AL}$ & Negative & - & - & - \\
\hline 19 & Positive (4.7) & A & $\mathrm{AL}$ & Negative & - & - & - \\
\hline 20 & Inconclusive (3.8) & A & PL & Negative & - & - & - \\
\hline 21 & Inconclusive(3.75) & A & PL & Negative & - & - & - \\
\hline 22 & Inconclusive (3.5) & $\mathrm{A}$ & PL & Positive & Positive & Positive & Negative \\
\hline 23 & Positive (25.9) & $\mathrm{A}$ & PL & Positive & Positive & Positive & Negative \\
\hline 24 & Positive (4.3) & A & $\mathrm{AL}$ & Negative & - & - & - \\
\hline 25 & Positive (9.9) & A & PL & Positive & Positive & Positive & Negative \\
\hline \multirow[t]{2}{*}{26} & Inconclusive (3.1) & A & $\mathrm{AL}$ & Positive & Positive & Positive & Negative \\
\hline & & $\mathrm{B}$ & PL & Positive & Positive & Positive & Negative \\
\hline 27 & Positive (6.0) & $\mathrm{A}$ & $\mathrm{AL}$ & Negative & - & - & - \\
\hline \multirow[t]{2}{*}{28} & Positive (5.2) & A & AL & Negative & - & - & - \\
\hline & & & $\mathrm{B}$ & PL & Positive & Positive & Negative \\
\hline 29 & Positive (8.1) & A & $\mathrm{AL}$ & Negative & - & - & - \\
\hline \multirow[t]{3}{*}{30} & Positive (8.1) & A & $\mathrm{AL}$ & Positive & Positive & Positive & Negative \\
\hline & & B & PL & Positive & Positive & Positive & Negative \\
\hline & & $\mathrm{C}$ & PL & Positive & Positive & Positive & Negative \\
\hline
\end{tabular}

A: retrofaryngeal lymphnode; B: prescapular lymphnode; C: lung; D: liver; PL: caseous lesion presence; AL: caseous lesion absence; SICTT: single intradermal comparative tuberculin test; PCR: polymerase chain reaction; M: Mycobacterium.

The PCR for MTBC detection was described by Niyaz Ahmed et al. (1999) and uses primers NZ1 (5'CGACAGCGAGCAGCTTCTCGCTG 3') and NZ2 (5'GTCGCCACCACGCTGCTGGTCAGTG 3') specific for IS 1081, only present in MTBC.

Amplification was performed in a total volume of 50 $\mu$, with $200 \mu \mathrm{M}$ of each dNTP, 1X PCR buffer $(10 \mathrm{mM}$ Tris-HCL, pH 8.0; $50 \mathrm{mM} \mathrm{KCL),} 2 \mathrm{mM} \mathrm{MgCl} 2,25$ pmol of each primer (NZ1 and NZ2), 1.25 U Taq DNA polymerase and $10 \mu \mathrm{l}$ of DNA. The PCR reaction consisted of an initial denaturation of $95^{\circ} \mathrm{C}$ for $4 \mathrm{~min}, 30$ cycles including $94^{\circ} \mathrm{C}$ for $1 \mathrm{~min}, 63^{\circ} \mathrm{C}$ for $90 \mathrm{~s}$ and $72^{\circ} \mathrm{C}$ for 1 min followed by final extension at $72^{\circ} \mathrm{C}$ for $10 \mathrm{~min}$. The expected size of the amplified product was $306 \mathrm{bp}$.

For differentiation between $M$. bovis and $M$. tuberculosis we used the system described by De Los Monteros et al. (2002), adding $10 \mu \mathrm{l}$ of bacterial lysate to a PCR mix of $50 \mu \mathrm{l}$ containing dNTP, buffer, $\mathrm{MgCl}_{2}$ and Taq DNA polymerase as described above and $30 \mathrm{pmol}$ of the forward primer pncATB-1.2 (ATGCGGGCGTTGATCTCGTC) complementary to part of pncA that is shared both species, and species-specific reverse prim- 
ers pncAMB-2 (CGGTGTGCCGGA-GAAGCCG) and pncAMT-2 (CGGTGTGCCGGAGAAG-CGG), specific for M. bovis and M. tuberculosis respectively. After initial denaturation at $95^{\circ} \mathrm{C}$ for $10 \mathrm{~min}$, amplification was obtained with 30 cycles of $94^{\circ} \mathrm{C}$ for $1 \mathrm{~min}, 67^{\circ} \mathrm{C}$ for 1 min, and $72^{\circ} \mathrm{C}$ for 1 min was carried out, followed by a final extension step.

Positive PCR controls were $M$. bovis AN5 (ATCC15755) and M. tuberculosis $\mathrm{H}_{37} \mathrm{RV}$ (ATCC 27294), and ultra pure water was used as negative control. Amplification reactions were carried out in a Peltier Thermal Cycler-100 (MJ Research).

Analysis of the amplified products was performed by means of electrophoresis in $1.3 \%$ agarose gel with TBE $0.5 \mathrm{X}$ running buffer $(0.045 \mathrm{M}$ TRIS-Borate and $1 \mathrm{mM}$ of EDTA pH 8.0). Gel was stained with ethidium bromide, visualized with a UV transiluminator (300-320 $\mathrm{nm})$ and photographed by a fotodocumentation system (Kodak Digital Camera DC/120 Zoom) and analyzed with software 1D Image Analysis (Kodak Digital Science).

Fisher and Mann-Whitney tests were performed using MedCalc ${ }^{\circledR}$ software version 8.2.0.2 and Minitab ${ }^{\circledR}$ version 14.1.

Among the 30 animals submitted to sanitary slaughter, all presented pathologic signs of TB: 28 (93.3\%) presenting localized TB lesions at retrofaryngeal lymphnode, 1 animal (3.3\%) with generalized TB including caseous lesions in retrofaryngeal and prescapular lymphnodes, lung, and liver, and another animal presenting respiratory TB with lung lesion. Eighteen animals $(60 \%)$ had a culture positive sample (27 of $42,64.3 \%$ ) from at least one of the forementioned tissues, including 15 retrofaryngeal lymphnodes $(55.5 \%), 9$ prescapular lymphnodes (33.3\%), 2 lungs (7.4\%), and 1 liver (3.7\%) (Table).

Bacteria present in every analyzed culture belonged to MTBC as determined by PCR with primers NZ1 and NZ2. Additionally, using the $p n c A$ based PCR, all were identified as M. bovis as shown in the Table.

There was no statistically significant association (Fisher's exact test, $\mathrm{p}=0.7152$ ) between the presence of lesion at retrofaryngeal lymphnodes and positive culture. There was no statiscally significant association (Mann-Whitney test, $\mathrm{p}=0.9325$ ) between SICTT value and at least one analyzed positive sample for microbiological culture.

Of the 30 animals studied here, 24 (80\%) were positive (> $4 \mathrm{~mm}$ ) to SICTT, and $6(20 \%)$ were inconclusive (2-3.9 mm). Inconclusive results can occur due to recent infection (30 to 50 days), end of pregnancy, malnutrition, and anergy in advanced cases of infection (Monaghan et al. 1994, Brasil 2005). Other factors are test-related and include dose of application and tuberculin conservation, both of which influence the test result (Monaghan et al. 1994). Estimates of the sensitivity of tuberculin test range from $68-95 \%$ while specificity is estimated to be 96-99\% (Monaghan et al. 1994), and in the present study the sensitivity of SICTT was $24 / 30$ (80\%). Silva et al. (2006) compared the seric levels of adenosine diaminase (ADA) to SICTT results during diagnosis of bovine TB, but the authors reported the im- possibility to establish a meaningful cutoff for ADA seric values, concluding that the latter in its present form is of no use as an auxiliary test for diagnosis of bovine TB.

Among the 30 animals with samples submitted to microbiological culture, 18/30 (60\%) had some Mycobacterium sp. culture positive sample. When analyzing culture positivity among animals with SICTT positive our inconclusive outcome, in 6 of $24(25 \%)$ positives and 2 out of $6(33.3 \%)$ inconclusives, no positive cultures were obtained, demonstrating the absence of relation between SICTT and cultures results $(p=0.9325)$. In a study performed on 2500 bovines from six slaughterhouses in Mexico, 400 (16\%) animals presented typical TB lesions during routine inspection of carcasses at abbatoirs between July 1996 and January 1997, and 336 (84\%) presented lymphnode lesions (Milian-Suago et al. 2000) and $308(77 \%)$ samples were positive for Mycobacterium sp. upon culturing and histologic examination. In another Brazilian study, peformed by Zanini et al. (2001), $42.6 \%$ of 54 lymphnode samples from slaughterhouses in the Southeast region of the country were culture-positive for Mycobacterium sp. and identified by biochemical testing and Ziehl-Neelsen (ZN), as M. bovis. In contrast (Araújo et al. 2005) 72 samples were selected during slaugther inspection in abattoirs in the state of Mato Grosso do Sul, Brazil, obtained only $23.6 \%$ of samples showed colonies suggestive of mycobacteria that were confirmed to be acid-fast bacilli by ZN. In the present study, mycobacteria were isolated in $64.3 \%$ of the samples, including half of the evaluated retrofaryngeal lymphnodes samples and all prescapular lymphnodes (9), lungs (2), and liver (1) samples. When analyzing culture efficacy among animals, $60 \%$ were positive for mycobacteria. There was no significant association between presence of retrofaryngeal lymphnode lesions and positivity at microbiological culture $(\mathrm{p}>0.05)$. This absence of association may be due to sampling bias, as no negative animal at SICTT was evaluated.

In the present study, all isolated mycobacteria were characterized as M. bovis by PCR analysis. Araújo et al. (2005) reported that among 72 bovine lymphnode slaughterhouse samples, 17 were positive for mycobacteria, and 13 were confirmed by PCR with primers JB21 and JB22 as M. bovis. Two of the four remaining samples were identified as belonging to MTBC while the other two did not belong to the MTBC, as measured by restriction enzyme analysis (PRA) of the hsp65 gene.

Additionally, Shah et al. (2002) reported genetic analysis of isolates from human, bovine, swine, wild mammals, and guinea pigs sources that had been submitted to conventional biochemical test. Using the pncA direct PCR system, we demonstrated a confirmed $100 \%$ specifity of the genotyping procedure when compared to conventional procedures.

We conclude from our data, that all animals that presented positive or inconclusive SICTT were infected with $M$. bovis as evidenced by PCR based analysis. However, due to lack of conventional identification procedures and animals with negative SICTT and without infection with $M$. tuberculosis, no conclusions on accuracy of the PCR based procedures can be drawn presently, requiring additional studies. 


\section{REFERENCES}

Abrahão RMC 1999. Tuberculose humana causada pelo Mycobacterium bovis: considerações gerais e a importância dos reservatórios animais. Arch Vet Sci 4: 5-15.

Araújo CP, Leite CQF, Prince KA, Jorge KSG, Osório ALAR 2005. Mycobacterium bovis identification by molecular method from post-mortem inspected cattle obtained in abattoirs of Mato Grosso do Sul, Brazil. Mem Inst Oswaldo Cruz 100: 749-752.

Bermer-Melchior P, Drugeon HB 1999. Inactivation of Mycobacterium tuberculosis for DNA typing analysis. J Clin Microbiol 37: 2350-2351.

Bouvet E, Casalino E, Mendoza-Sassi G, Lariven S, Valee E, Pernet M, Gottot S, Vachon F 1993. A nosocomial outbreak of multidrug-resistant Mycobacterium bovis among HIVinfected patients. A case-control study. AIDS 7: 1453-1460.

Brasil 2005. Ministério da Agricultura, Pecuária e Abastecimento. Programa Nacional de Controle e Erradicação de Brucelose e Tuberculose. www.agricultura.gov.br; acess: 30/06/2005.

De Los Monteros LEE, Galán JC, Gutiérrez SS, Marín JFG, Dominguez L, Rafael L, Baquero F, Gomez-Mampaso E, Blázquez J 1998. Allele-specific PCR method based on pncA and $o x y R$ for distinguishing Mycobacterium bovis from Mycobacterium tuberculosis: Intraspecific $M$. bovis pncA sequence polymorphism. J Clin Microbiol 36: 239-242.

Haddad N, Masselot M, Durand B 2004. Molecular differentiation of Mycobacterium bovis isolates. Review of main techiques and applications. Res Vet Sc 76: 1-18.

Kantor IN 1979. Bacteriologia de la Tuberculosis Humana y Animal, OPAS/OMS. Nota técnica 11, 63 pp.

Kantor IN, Ritacco V 1994. Bovine tuberculosis in Latin America and the Caribbean: current status, control and erradication programs. Vet Microbiol 40: 5-14.

Milian-Suago F, Salman MD, Ramirez C, Payeur JB, Rhyan JC, Santillan M 2000. Identification of tuberculosis in the catlle slaughtered in Mexico. Am J Vet Res 61: 86-89.

Monaghan ML, Doherty ML, Collins JD, Kazda JF, Quinn PJ 1994. The tuberculin test. Vet Microbiol 40: 111-124.

Niyaz Ahmed AS, Khan JR, Ganai NA 1999. DNA amplification assay for rapid detection of bovine tubercle bacilli in semen. Anim Repro Sci 57: 15-21.

Silva MR, Mota PMPC, Leite RMH, Lobato, FCF, Leite, RC, Lage, AP 2006. Evaluation of adenosine deaminase seric activity in the diagnosis of bovine tuberculosis. Mem Inst Oswaldo Cruz 101: 391-395.

Singh SK, Verma R, Shah DH 2004. Molecular fingerpriting of clinical isolates of Mycobacterium bovis and Mycobacterium tuberculosis from India by restriction fragment lenght polymorphism (RFLP). J Vet Sci 5: 331-335.

Shah DH, Verma R, Bakshi CS, Singh RK 2002. A multiplex-PCR for the differentation of Mycobacterium bovis and Mycobacterium tuberculosis. FEMS Microbiol Lett 214: 39-43.

Wards BJ, Collins DM, Lisle GW 1995. Detection of Mycobacterium bovis in tissues by polymerase chain reaction. Vet Microbiol 43: 227-240.

Zanini MS, Moreira EC, Lopes MTP, Oliveira RS, Leão SC, Fiovaranti RL, Roxo E, Zumarraga M, Romano MI, Cataldi A, Salas CE 2001. Mycobacterium bovis: polymerase chain reaction identification in bovine lymphonode biopses and genotyping in isolates from Southeast Brazil by spoligotyping and restriction fragment length polymorphism. Mem Inst Oswaldo Cruz 96: 1-5. 